\title{
Quality Assessment of Rain and Storm Water Runoff for Nairobi City Industrial and Sub-Urban Areas
}

\author{
Eng Evans Mugera Lusigi \\ Department of Environmental and \\ Biosystem Engineering \\ University of Nairobi, P.O Box \\ 30197, 00100, Harry Thuku Road, \\ Nairobi, Kenya
}

\author{
Duncan Onyango Mbuge \\ Department of Environmental and \\ Biosystem Engineering \\ University of Nairobi, P.O Box \\ 30197, 00100, Harry Thuku Road, \\ Nairobi, Kenya
}

\author{
John Paul Obiero \\ University of Venda, \\ Private Bag X5050, Thohoyandou, \\ Limpopo Province, 0950, South \\ Africa.
}

\author{
Stephen Conrad Ondieki \\ Department of Environmental and \\ Biosystem Engineering \\ University of Nairobi, P.O Box \\ 30197, 00100, Harry Thuku Road, \\ Nairobi, Kenya
}

\author{
Peter Kuria Ndiba \\ Department of Civil and Construction Engineering, \\ University of Nairobi, P.O Box 30197, 00100, Harry \\ Thuku Road, Nairobi, Kenya
}

\begin{abstract}
Nairobi like most cities in the world is faced with water shortages because all the surface water sources have been tapped and the ground water overexploited, yet the water demand continues to rise as the population grows. The city must therefore seek alternative means of water supply. One of the promising sources is rainwater harvesting, which has successfully been adopted to supply water in many other cities. However, there is a concern about the quality of the rainwater falling through a heavily industrialized city atmosphere and flowing over polluted grounds. There is need to determine the quality of rainwater and the resulting storm water so as to make a decision on the best application or treatment of the water. The purpose of the study was therefore to determine the physical and chemical properties of rain and storm water runoff in sub-urban and industrial settings in Nairobi. Two sites were indentified namely Upper Kabete Campus (heavily vegetated agricultural suburb), and Jomo Kenyatta International Airport (heavily industrialized area of the city) to assess the water quality of rainwater received and storm water runoff exiting to drains. Water samples were collected directly from falling rain and also from runoff water at the sites for laboratory analysis. The samples were analyzed for water quality parameters namely $\mathrm{pH}$, alkalinity, hardness, total dissolved solids, chlorides, calcium, nitrates, iron. The results from the two sites were compared statistically. It was found that the quality of rain water does not differ significantly in physiochemical parameters at 0.05 significant levels between the sub-urban and industrial setting. The falling rainwater was only slightly above the WHO requirements and required only modest treatment whole the storm water was significantly above the WHO limits and either need treatment or may be used for non potable application. Results of the study are useful in addressing challenges of water quality partly by encouraging use of rain and storm water for non
\end{abstract}

portable uses and preserving the limited treated water for essential household uses.

\section{Keywords}

Water quality, Pollution, land use patterns and Groundwater recharge

\section{INTRODUCTION}

The population of Cities in Africa is growing by $6-9 \%$ per year and the demand for increasing amounts of water can no longer be met by sources within the urban areas. This lack of water availability as well as heavy pollution of water sources in and around cities has made basin transfers from distant location inevitable. Cities are intimately tied to national prospects for sustained economic growth and sustainable development. The ability of Cities to function as social, cultural and economic centres is shaped by urban population dynamics (UNFPA, 1996).

Nairobi occupies an area of about $700 \mathrm{~km}^{2}$ and was projected to have a population of 3.8 million by 2015 . The City has a growing problem of water supply which has its roots in the original choice of the site. Initially Nairobi was not originally planned to be a large conurbation and the available water resource was sufficient only for a smaller population. To meet the growing demand, water has to be pumped from locations outside the city (Mitulla, 2003).

However, apart from water shortages, especially during the dry seasons, the other problem has been one of distribution (Mumero and Mwangi, 2006). Annual expenditure on water and sewerage declined dramatically in real terms between 1981 and 1987, capital expenditure by 91 per cent, expenditure on maintenance by 68 per cent and the situation has not shown any significant improvement since then (Muthoni, 1998). 
With Nairobi's population rising beyond the five million mark, the projected demand for water in the City in 2020 and 2030 stands at 1.6 million and 2.2 million cubic metres respectively. As the city continues to grow both in population and the physical extent, demand for water has over stripped supply. Nairobi is getting less water today than it was getting 10 years ago, as colonial era supply systems broke down from neglect. Some of the causes of the current supply deficit in the city include the 15 year time lag and delay in new investment in water storage, slow rehabilitation of water infrastructure and lack of investment in new water sources (Wafula, 2010).

Nairobi faces severe water scarcity. Water demand exceeds water supply by about $200,000 \mathrm{~m}^{3}$ per day. Surface water is highly polluted. Up to $50 \%$ of drinking water is lost due to insufficient, outdated infrastructure and illegal connections. Only $50 \%$ of households have access to piped drinking water. Nairobi still has inadequate capacity to manage the increasing demand for water, especially in Nairobi's informal settlements, where water is sold at water kiosks, often at a higher price than piped water. Untreated waste and wastewater both pose a danger to human health and lead to eutrophication, deoxygenation and habitat modification of riverine systems. Old infrastructure causes leaks and losses. In 2003, about $50 \%$ of drinking water from the Aberdare Range did not reach the city (Dudley \& Stolton, 2003).

Water in most of the Nairobi River sub-basins was found to be highly polluted according to research findings carried out by Africa Water Network in 2001. Thus, urgent remedial measures are required in order to avert serious problems within these subbasins. One of the symptoms that indicate clean treated water is not available has been manifested by insurgence of water related diseases in the City namely cholera and typhoid.. However, despite many technological advances in development, provision of safe water within reasonable distance from homesteads has remained a problem. In spite of the suffering experienced as a result of water inaccessibility much of the rain water escapes into rivers and underground (Mulei \& Ongwenyi, 1992).

Agriculture and industrial activities have both direct and indirect effects on the quality of surface water and groundwater and are among the leading causes of water quality degradation, mainly as a result of the excessive use of agrochemicals and discharge of effluents from industrial plants. It should be noted that poor documentation of studies carried out within the city of Nairobi in different settings poses challenges of water quality analysis since there is no data for comparison.

Decreasing water quality and pollution of rivers and groundwater resources is one of the main threats to water sustainability in urban developed areas. The main sources of point and non-point pollution (pathogens, organic and inorganic pollutants) are agricultural runoff, untreated industrial and domestic wastewater, as well as storm water and urban runoff. Although technical solutions have improved significantly, wastewater treatment and sanitation is still a global problem in megacities. Decreasing water quality is also caused by degradation and land use changes in the catchment area. It has been shown that forest protection within the watershed leads to improved water quality while deforestation results in poor water quality (Dudley \& Stolton, 2003).

The city must therefore seek alternative means of water supply. One of the promising sources is rainwater harvesting, which has successfully been adopted to supply water in many other cities. However, it is important to confirm the quality of the rainwater before it is recommended for adoption in the city. There is need to determine the quality of rainwater and the resulting storm water so as to make a decision on the best application or treatment of the water.

The water in a raindrop previously used to be one of the cleanest sources of water available, however due to the several sources of atmospheric pollution such as vehicles, industries, emissions from the use of charcoal and firewood, and other municipal sources such as the open burning of waste the situation has changed the scenario significantly. Air pollution adversely affects the quality of rainwater within the city which affects human health and the environment. Storm water runoff is generated when precipitation from rain events flows over land or impervious surfaces such as paved streets, parking lots and rooftops and does not seep into the ground. Consequently, it accumulates and transports chemicals, nutrients, sediment or other pollutants and debris. If the runoff is not captured or it is discharged without first being treated, it can adversely affect water quality

The study therefore determined the various water quality parameters for falling rain and runoff in two different settings and compare the extent of variation of corresponding values of the said parameters for the two different settings. The study is intended to provide scientific information that can be used by the policy makers and water managers in planning for availability of good quality water.

Potential long term benefits of ascertaining the quality of water will subsequently provide a platform for further investigations in the changing trends of the quality parameters as impacted by rainfall intensity, duration as well as between the short and long rainfall season within a calendar year.

The overall objective was to determine and compare the water quality parameters of falling rainwater and storm water runoff for an industrial setting and suburban area.

The specific objectives of the study were as follows:

i) To determine the pertinent quality parameters of rainwater and storm water runoff in a sub urban area and an industrial setting:

ii) To establish the change in quality parameters of falling rain water and storm water runoff over a rainy season for an industrial setting area and Suburban area.

\section{MATERIAL AND METHODS}

Two sites representing different land use and environmental settings of the City of Nairobi were identified for sampling and analysis of rainfall and runoff in accordance with the purpose of the study. One of the sites was at Jomo Kenyatta International Airport which represented an industrial setting whilst the other site was at the College of Agriculture and Veterinary Sciences (Upper Kabete Campus), University of Nairobi, Kenya, which represented a sub-urban area partly occupied with urban agricultural activities and dense coverage with trees.

The falling rainwater was collected as follows: A water jar was placed at least two metres above ground in an open field to collect rain water. The jar was placed above the ground to avoid chances of contamination from water splashing from ground. Three samples were collected for each site and analysed. This was repeated for three storms.

Collection of storm water involved collecting of three samples of water from storm drains within the precincts of the research area. The storm water runoff was collected for three different storms. 
The collected samples were analyzed at the Public Health Laboratory, Department of Civil and Construction Engineering, University of Nairobi where physical and chemical analysis was carried out.

The concentration of each parameter was determined in each sample. The water samples were analysed for physicochemical characteristics. A Total of 15 physicochemical parameters were analyzed namely:

1. Colour attributes: Apparent Colour (AC), True Colour (TC), Conductivity, Turbidity (TU).

2. Physical properties: $\mathrm{pH}$, Calcium hardness, Total Alkalinity, Total Suspended Solids, Total Dissolved Solids, Total Hardness.

3. Dissolved Minerals: Dissolved Oxygen, Chloride, Nitrate and Nitrite including some heavy metals namely Iron and Manganese.

Samples were analysed according to Standard Methods for Examination of Water and Waste water (APHA, 1998) and the Association of Official Analytical Chemists (AOAC).

\section{RESULTS AND DISCUSSION 3.1 Colour attributes}

The results for the colour attributes are presented in Figure 1.

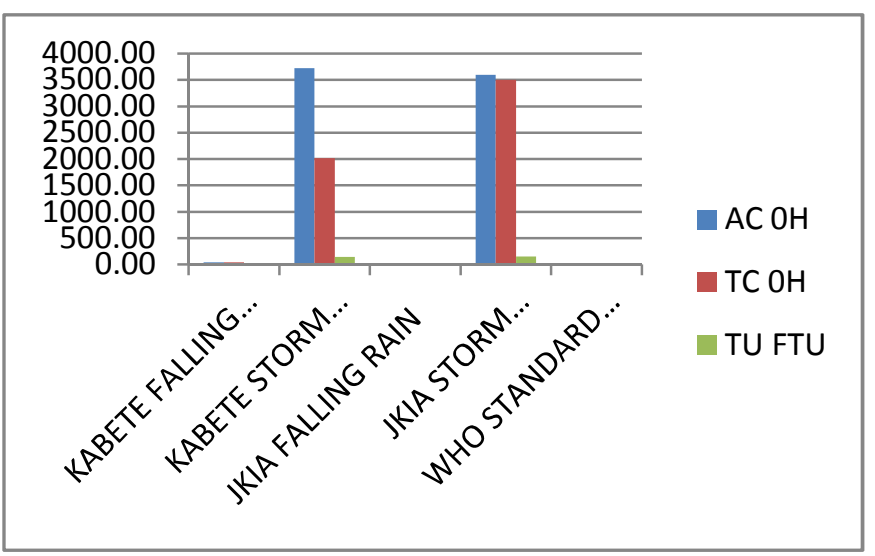

Figure 1: Colour Attributes for each site

\section{Colour (Apparent)}

Apparent color is the color of the whole water sample, and consists of color from both dissolved and suspended components. The presence of color in water does not necessarily indicate that the water is not potable. Color-causing substances such as tannins may be harmless.

The means of Apparent colour (AC) for falling rain ranged from of 41.67 TCU at Kabete to $25 \mathrm{TCU}$ at Jomo Kenyatta with an overall mean of 33.33. The means for TCU for falling rainfall ranged from $3725 \mathrm{TCU}$ at Kabete to $3600 \mathrm{TCU}$ at Jomo Kenyatta for storm water with an overall mean of $3662.2 \mathrm{TCU}$ as presented in Figure 1. In both scenarios there was no significant differences ( $\mathrm{P}=0.0 .5$, ANOVA) between the two sampling site. The high values recorded at Kabete are probably due to effects of air pollution arising from use of chemicals to boost agricultural production and emissions from Zero grazing units (Wigley and Jones 1985) In terms of its usage, colour influences the taste and acceptability for use and so date WHO and NEMA have not yet developed any guidelines Relatively lower values recorded at JKIA as compared to Kabete is partly attributed to low level of pollution as a result of a well kept and maintained environment at the airport.

\section{True colour}

True colour is the colour of water after filtering all the suspended material Sediments. The True colour (TC) means ranged from of 36.67 TCU at Kabete to $20 \mathrm{TCU}$ at Jomo Kenyatta with an overall mean of $28.33 \mathrm{TCU}$ for falling rainfall while means ranged from of $2016 \mathrm{TCU}$ at Kabete to $3500 \mathrm{TCU}$ at Jomo Kenyatta for storm water with an overall mean of 2758 TCU.(Figure 1) In both scenarios there was no significant differences ( $\mathrm{P}=0.0 .5$, ANOVA) between the two sampling sites. The high value recorded at Jomo Kenyatta are probably due to effects of water pollution arising from industrial effluents mainly oils and greases

Colours in natural waters can originate from decomposition of organic matter and discharge of certain waste. Colours interfere with penetration of light and affects photosynthesis. It may also hamper oxygen absorption from the atmosphere.

\section{Turbidity}

Turbidity measures water clarity or the ability of light to pass through water. Turbidity is a measure of the amount of particulate matter and dissolved color that is suspended in water.

The Turbidity (TU) means ranged from of $2.3 \mathrm{NTU}$ at Kabete to 1.7 NTU at Jomo Kenyatta with an overall mean of 2FTU for falling rainfall the means ranged from of $145 \mathrm{NTU}$ at Kabete to 150 NTU at Jomo Kenyatta for storm water with an overall mean of 147.5 (Figure 1) In both scenarios there was no significant differences ( $\mathrm{P}=0.0 .5$, ANOVA) between the two sampling sites. The high value recorded at Jomo Kenyatta and Kabete for stormwater are probably due attributed to Chemicals from fertilizers, pesticides and industrial effluents make their way into the storm water.

All The values for turbidity for falling rain in both sites and storm water were beyond the required WHO limits. The measurement of turbidity is a key test of water quality. As per world health organization standards drinking water levels should be as low as 0.1 NTU. For this reason, the falling rainwater in Nairobi needs treatment so as to remove turbidity. However this may not apply to storm water which is recommended for use in non potable activities such as watering the city flower gardens and parks where treated water is currently used.

\subsection{Physical Properties}

The results of the tests for physical properties are presented in Figure 2. 


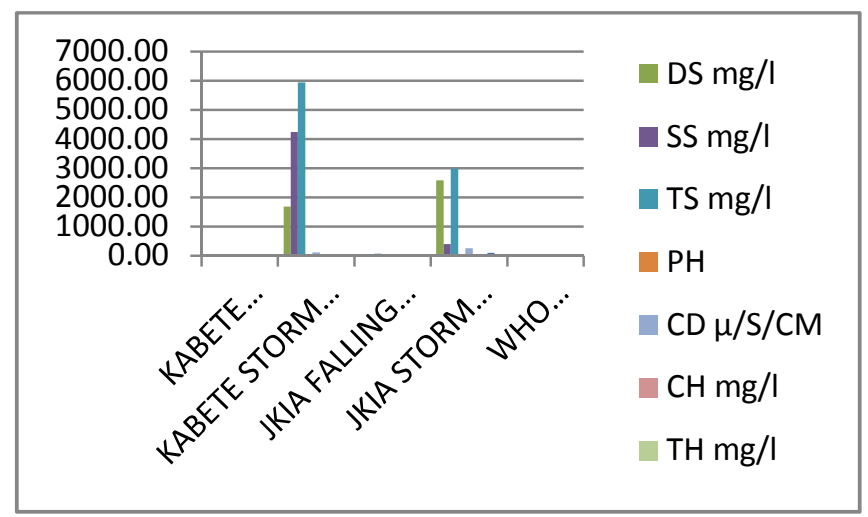

Figure 2: Trends in Physical Properties for each site

\section{pH}

The $\mathrm{pH}$ means ranged from of 7.61 at Kabete to 7.51 at Jomo Kenyatta with an overall mean of 7.56 for falling rainfall while the means were similar at 7.55 at both sites for storm water with an overall mean of 7.55. In both scenarios there was no significant differences $(\mathrm{P}=0.0 .5$, ANOVA) between the two sampling sites. The study revealed that the $\mathrm{pH}$ value of the both rain and storm water at both sites is slightly alkaline but within the permissible limits by NEMA (1999) standards.

The slight difference in $\mathrm{pH}$ levels observed is probably due to the effluent from industrial wastes containing organic waste which is discharged into the storm water (Chennakrishnan, 2008). Agricultural activities contributed to elevated $\mathrm{pH}$ primarily in the form of nutrient runoff (most commonly fertilizer), as observed from Kabete where agriculture is practiced.

\section{Total dissolved solids}

This refers to natural or added solutes present in water which includes the dissolved and suspended solids. Basically Solids are particles of sand, silt, clay, and organic materials found in the water and are usually measured as a concentration, milligrams per liter (mg/L).

The Dissolved Solids (DS) means ranged from of $53.33 \mathrm{mg} / 1$ at Kabete to $60 \mathrm{mg} / 1$ at Jomo Kenyatta with an overall mean of $56.56 \mathrm{mg} / \mathrm{l}$ for falling rainfall the means ranged from of $1690 \mathrm{mg} / 1$ at Kabete to $2590 \mathrm{mg} / \mathrm{l}$ at Jomo Kenyatta for storm water with an overall mean of 2140. (Figure 2) In both scenarios there was no significant differences ( $\mathrm{P}=0.0 .5$, ANOVA) between the two sampling sites.

The high value recorded at Jomo Kenyatta and Kabete for stormwater are probably due to human agricultural activities in Kabete resulting in erosion of soil that forms part of the runoff while in Jomo Kenyatta the dust washed away from pavements make their way into the storm water.

The values for Total suspended solids for falling rain in both sites are within the allowable limits whilst the values for storm water in both sides are extremely much higher than the allowable limits The tolerance limit for Total Dissolved Solids is $500 \mathrm{mg} / \mathrm{l}$. High levels of suspended solids can cause problems for aquatic organisms, both as the solids travel through the water and after they are deposited (EPA. 2003).

\section{Electrical Conductivity}

Electrical Conductivity is a measure of how much total salt is present in the water. The more the ions, the higher the conductivity (Mosley et al., 2004). The Electrical Conductivity (EC) means ranged from of $55 \mu \mathrm{S} / \mathrm{m}$, at Kabete to $14.5 \mu \mathrm{S} / \mathrm{m}$, at Jomo Kenyatta with an overall mean of $34.7 \mu \mathrm{S} / \mathrm{m}$, for falling rainfall while the means ranged from $110.5 \mu \mathrm{S} / \mathrm{m}$, at Kabete to $256 \mu \mathrm{S} / \mathrm{m}$, at Jomo Kenyatta for storm water with an overall mean of $183.25 \mu \mathrm{S} / \mathrm{m}$. (Figure 2). In both scenarios there was no significant differences ( $\mathrm{P}=0.0 .5$, ANOVA) between the two sampling sites.

High quality deionized water has a conductivity of about 5.5 $\mu \mathrm{S} / \mathrm{m}$, Allowable typical drinking water in the range of 5-50 $\mathrm{mS} / \mathrm{m}$. All the parameters are beyond the allowable range for drinking water except the value for falling rainfall in Jomo Kenyatta. The high values of $\mathrm{CD}$ in both sites for storm water could be attributed to release of effluents and agricultural fertilizers and blood containing nitrogenous compounds into runoff water which are nitrified to ammonium-nitrogen and nitrate resulting in high EC (Koushik and Saksena, 1999). CD was generally within permissible limits along the stream and this attributed to the dilution effect and other natural processes

\section{Total Hardness}

Hardness is a natural characteristic of water which can enhance its palatability and consumer acceptability for drinking originally taken to be the capacity of water to destroy the lather of soap.

The Total Hardness (TH) means ranged from of $48 \mathrm{mg} / 1$, at Kabete to $8 \mathrm{mg} / 1$, at Jomo Kenyatta with an overall mean of $28 \mathrm{mg} / 1$, for falling rainfall. (Figure 2) There was no significant differences $(\mathrm{P}$ $=0.0 .5$, ANOVA) between the two sampling sites for falling rainfall. Avoid one sentence paragraph

The values for hardness for rain water in Kabete was attributed to emission of calcium containing chemicals in the air from agricultural related activities for crop production and livestock production.

The maximum desirable limit for Total Hardness is $300 \mathrm{mg} / \mathrm{l}$. (USEPA, 1986). Most of the values of the water samples were less than $60 \mathrm{mg} / 1$ hence the water is classified as soft

\section{Total Alkalinity}

The alkalinity of natural water is generally due to the presence of bicarbonates formed in reactions in the soils through which the water percolates. It is a measure of the capacity of the water to neutralise acids and it reflects its so-called buffer capacity (its inherent resistance to $\mathrm{pH}$ change

The Total Alkalinity (TA) means ranged from of $28 \mathrm{mg} / 1$ at Kabete to $21 \mathrm{mg} / 1$ at Jomo Kenyatta with an overall mean of $24.7 \mathrm{mg} / 1$, for falling rainfall while the means ranged from of $42 \mathrm{mg} / 1$, at Kabete to $98 \mathrm{mg} / 1$ at Jomo Kenyatta for storm water with an overall mean of $70 \mathrm{mg} / \mathrm{l}$. (Figure 2).In both scenarios there was no significant differences ( $\mathrm{P}=0.0 .5$, ANOVA) between the two sampling sites

The storm water value at Jomo Kenyatta was higher different which was attributed to $\mathrm{CaCO} 3$, being leached from rocks and soil due to urban development effluent discharges from the industrial plants whilst for Kabete it is attributed to $\mathrm{CaCO} 3$, being leached from soil due to cultivation of farms. All the values of the water samples were within the range of $20-200 \mathrm{mg} / \mathrm{L}$ hence the water is classified as typical fresh water. Alkalinity is significant in the treatment of wastewater and drinking water because it will influence treatment processes such as anaerobic digestion. 


\subsection{Dissolved Minerals}

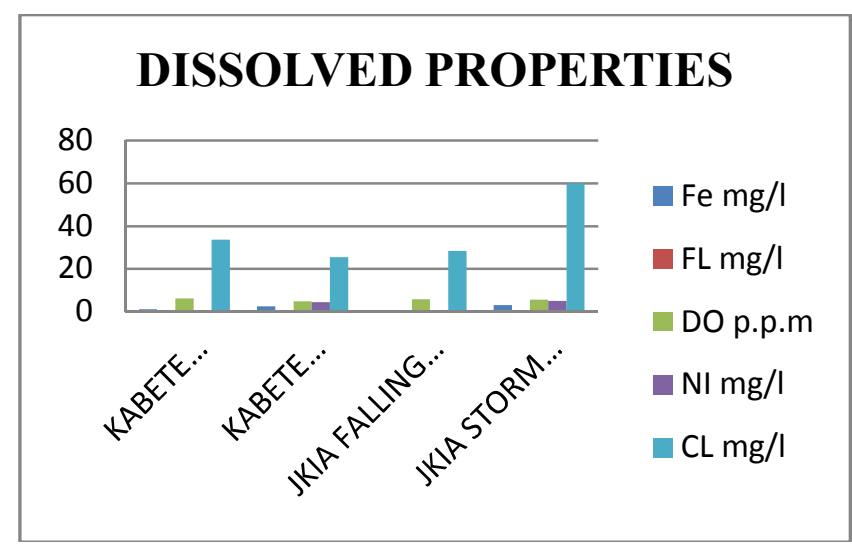

Figure 3: Trends in dissolved solids for each site

\section{Iron $(\mathrm{Fe})$}

Iron is a chemical element with symbol Fe and atomic number 26. It is by mass the most common element on Earth, forming much of Earth's outer and inner core. Iron is the second most abundant metal in the earth's crust, of which it accounts for about $5 \%$.Elemental iron is rarely found in nature, as the iron ions $\mathrm{Fe} 2+$ and $\mathrm{Fe} 3+$ readily combine with oxygen- and sulfur-containing compounds to form oxides, hydroxides, carbonates, and sulfides.

The Iron (Fe) means ranged from of $1.1 \mathrm{mg} / 1$ at Kabete to $0.1 \mathrm{mg} / 1$ at Jomo Kenyatta with an overall mean of $0.6 \mathrm{mg} / 1$ for falling rainfall while the means ranged from of $2.5 \mathrm{mg} / 1$ at Kabete to $3 \mathrm{mg} / 1$ at Jomo Kenyatta for storm water with an overall mean of $2.75 \mathrm{mg} / \mathrm{l}$. (Figure 3). In both scenarios there was no significant differences ( $\mathrm{P}=0.0 .5$, ANOVA) between the two sampling sites.

The high value recorded at Kabete and Jomo Kenyatta for stormwater are probably due to Geological formations; acid drainage; effluent discharges from agricultural activities and industrial plants. Most of the values of the water samples were beyond the permissible limit except for falling rain at Jomo Kenyatta

\section{Fluoride(FL)}

Fluoride is an inorganic, monatomic anion of fluorine with the chemical formula F-Fluoride is the simplest anion of fluorine.(Wells, J.C. 2008)

All the samples taken from both sites for falling rain and storm water registered no presence of fluorides which was attributed to occurrence of fluoride ions on earth in several minerals, particularly fluorite, but are only present in trace quantities in water. Fluoride is added to public drinking water to prevent tooth decay. Fluoride is added to toothpaste and mouthwashes so it can be applied directly to the teeth to prevent tooth decay

\section{Dissolved Oxygen (DO)}

Dissolved oxygen measurements can be expressed as a concentration, milligrams per liter $(\mathrm{mg} / \mathrm{L})$, or as percent saturation (the amount of oxygen the water holds compared to what it could absorb at that temperature).
The Dissolved Oxygen (DO) means ranged from of $6.23 \mathrm{mg} / \mathrm{l}$ at Kabete to $5.9 \mathrm{mg} / 1$ at Jomo Kenyatta with an overall mean of $6.07 \mathrm{mg} / \mathrm{l}$ for falling rainfall while the means ranged from of $4.9 \mathrm{mg} / \mathrm{l}$ at Kabete to $5.6 \mathrm{mg} / \mathrm{l}$ at Jomo Kenyatta for storm water with an overall mean of $5.25 \mathrm{mg} / 1$. (Figure 3 ).

In both scenarios there was no significant differences $(\mathrm{P}=0.0 .5$, ANOVA) between the two sampling sites. The value at Kabete for falling rain was slightly higher for Jomo Kenyatta which was attributed to infusion of oxygen into the air a result of photosynthesis whilst the corresponding values for the storm water at both sites slightly lower due to contamination of storm water from fertilizers and industrial waste that affect the concentration of the dissolved oxygen. Currently NEMA and WHO have not yet developed guidelines for safe limits

\section{Nitrates (NI)}

Nitrate is a polyatomic ion with the molecular formula $\mathrm{NO}_{3}{ }^{-}$and a molecular mass of $62.0049 \mathrm{~g} / \mathrm{mol}$ The Nitrates (NI) means ranged from of $0.7 \mathrm{mg} / 1$ at Kabete to $0.4 \mathrm{mg} / 1$ at Jomo Kenyatta with an overall mean of $0.55 \mathrm{mg} / \mathrm{l}$ for falling rainfall while the means ranged from of $4.5 \mathrm{mg} / \mathrm{l}$ at Kabete to $5 \mathrm{mg} / \mathrm{l}$ at Jomo Kenyatta for storm water with an overall mean of $4.75 \mathrm{mg} / 1$. (Figure 3 ). In both scenarios there was no significant differences ( $\mathrm{P}=0.0 .5$, ANOVA) between the two sampling sites.

Permissible limit of nitrate is $45 \mathrm{mg} / \mathrm{l}$.. Most of the values of the water samples were beyond the permissible limit except for falling rain at Jomo Kenyatta. The storm water the values at Kabete and Jomo Kenyatta were higher which was attributed to agricultural runoff of animal wastes and nitrogen-containing fertilizers concentrations of nitrate in the environment and effluent from sewage respectively. In both sites the values were within the safe limits as the WHO standard is $50 \mathrm{mg} / 1$.

\section{Chlorides (CL)}

The chloride ion is the anion (negatively charged ion) $\mathbf{C l}^{-}$. It is formed when the element chlorine (a halogen) gains an electron or when a compound such as hydrogen chloride is dissolved in water or other polar solvents (Wells, John C. 2008) Chloride exists in all natural waters, the concentrations varying very widely and reaching a maximum in sea water (up to $35,000 \mathrm{mg} / \mathrm{l} \mathrm{Cl}$ ). The Chorides (CL) means ranged from of $33.67 \mathrm{mg} / 1$ at Kabete to $28.5 \mathrm{mg} / 1$ at Jomo Kenyatta with an overall mean of $31.37 \mathrm{mg} / 1$ for falling rainfall while the means ranged from of $25.5 \mathrm{mg} / 1$ at Kabete to $60 \mathrm{mg} / 1$ at Jomo Kenyatta for storm water with an overall mean of $42.75 \mathrm{mg} / 1$. (Figure 3 ). In both scenarios there was no significant differences ( $\mathrm{P}=0.0 .5$, ANOVA) between the two sampling sites

The storm water value at Jomo Kenyatta was higher which was attributed to pollution of a water by a sewage effluent since sewage is such a rich source of chloride, whilst for Kabete is due from soil and discharges from livestock enterprises. The safe limits by NEMA and WHO are $250 \mathrm{mg} / 1$ signifying that is values area within the safe limits set for drinking water. 


\section{CONCLUSION AND RECOMMENDATIONS}

\subsection{Conclusion}

Comparing the values of water quality parameters for both sites, it was concluded that water quality of parameters for falling rain and storm water are not significantly different for the two sites. For storm water the water quality values registered some differences which were attributed to the existence of varied land use characteristics since runoff from different land uses load significant amounts of nutrients and contaminants into water.

From the results for falling rain at both sites, It was established that the quality of water is reasonably portable for drinking purpose with only limited treatment and proper handling at harvesting. Additionally from the results of storm water. The water is not suitable for portable uses but can be used for car washing, pavement cleaning and flower gardening and for groundwater recharge.

\subsection{Recommendations}

The following recommendations are made in furtherance of the study carried

- To establish any relationship between of intensity of rain received and the water quality parameters

- To establish if there is any relationship between the rainfall duration and the water quality parameters.

- Ascertain the changes in water quality throughout a given rainfall season

- Compare water quality changes for a long and short rainfall season for same calendar year

\section{REFERENCES}

[1] Allan, J. D. 1995. Stream ecology. Structure and function of running waters.

[2] Chennakrishnan C, Stephren A, Manju T AND Raveen R 2008: Water Quality status of three vulnerable freshwater Lakes of Suburban Chennai, India.

[3] Chutter ,F.M 1998. Research on the Rapid Biological Assessment of Water Quality Impacts in streams and rivers

[4] Athi Water Services Board. June 2011. "Sasumua Dam Commissioned"

[5] Daniel B. and A. Keller, 1998. Environmental Science: Earth as a Living Planet.

[6] Deborah C., 1992. Water quality assessment: A guide to the use of biota, sediment and water in environmental monitoring, First edition 585p.

Dudley, N., Stolton, S. 2003. Running Pure: The importance of forest protected areas to drinking water.

[7] Duffus J H, 2002. Heavy metals" a meaningless term? (IUPAC Technical Report)," Pure and Applied Chemistry Vol. 74, pp. 793-807.

[8] EPA., 2003,"National Management Measures to Control Nonpoint Source Pollution from Agriculture."

[9] Fakayode, S. O. 2005. Impact of industrial effluents on water quality of the receiving Alaro River in Ibadan, Nigeria. Ajeam-Ragee, 10: 1-13
[10] Ganje, T. J. Selenium. 1966, Diagnostic Criteria for Plants and Soils: $394-404$

[11] Gullan, P.J. and P.S Cranston,. 2010. The Insects: An Outline of Entomology, 4th Edition. Blackwell Publishing UK: 584 pp.

[12] Hangsleben, M AND D Suh. 2006. Sediment pollution.

[13] Koushik, S. and Saksena,D. 1999: Physical-chemical limnology of certain fresh water bodies of central India

[14] Jambo ,N. 2011"Water supply to Nairobi". Retrieved 6 November 2011

[15] Kaluli J.W. Wangechi, C and Home P 2009. Surface water quality in Kenya's urban environment: Githurai Case Study

[16] Kupechella, C.E. and Hyland,M.C. 1989. Environmental Science

[17] Mafuta, C., R. Formo,K Nellemann,C and F. LI,. (EDS). 2011. Green Hills, Blue Cities: An Ecosystems Approach to Water Resources Management for African Cities. A Rapid Response Assessment. United Nations Environment Programme, GRID Arendal

[18] Mathuthu, A.S., Mwanga, K. AND Simoro, A. 1997. Impact Assessment of Industrial and Sewage Effluents on Water Quality of the receiving Marimba River in Harare.

[19] Mumma, A. M.. Lane E., Kairu, A Tuinhof. and R. Hirji,. 2011. Water Papers: Kenya Groundwater Governance Case Study. Water Unit, Transport, Water and ICT Department

[20] Mitullah,Winnie 2003. Understanding Slums: Case Studies for the Global Report on Human Settlements 2003: The Case of Nairobi, Kenya..UN-HABITAT,.Nairobi

[21] Msafiri, P.W. 2008. Opportunities and Challenges of Implementing PES in the Water Sector: A Kenya Buyer's Perspective. NCWSC, Nairobi

[22] NCWSC \& AWSB 2009. Strategic Guidelines for Improving Water and Sanitation Services in Nairobi's Informal Settlements. Nairobi City Water and Sewerage Company and Athi Water Services Board, Nairobi.

[23] Olima, wha 1997 "The Conflicts, Shortcomings and Implications of the Urban Land Management System in Kenya"Habitat International Vol 21, No 3, pp 319-331

[24] Phiri, O; P. Mumba,; B. H. Moyo ,Z. and . Kadewa W, 2005. Assessment of the impact of industrial effluents on water quality of receiving rivers in urban areas of Malawi. Int. J. EnvironSci Tech 2(3): 237-244

[25] Saggerson,.E.P.1991..Geology of the Nairobi Area.

[26] Robertson, A. and Davis W.. 1993. The selection and use of water quality indicators. p. 119-128.

[27] Gargi R. K., Rao R. J. and Saksena D. N. 2005. Correlation of molluscan diversity with physico-chemical characteristics of water of Ramsagar reservoir, India

[28] Stephen, F and Albert T. 2005. The Role of Groundwater in the Water-Supply of Greater Nairobi. .Retrieved 6 November 2011

[29] The streamkeeper's field guide: Watershed Inventory and Stream Monitoring Methods Revised Edition 
[30] Un-habitat 2010. Solid waste management in the world's cities: water and sanitation in the world's cities 2010. United Nations Human Settlements Programme. Earthscan, London

[31] UON/UNEP.2005..Water Quantity and Quality Assessment Desk Study..Department. of.Chemistry,. University of Nairobi The Nairobi River Basin. Programme.Phase III UNEP,Nairobi

[32] US EPA". water.epa.gov. ( 2013)-biosolids: targeted national sewage sludge survey report - overview |

[33] US EPA 1986: Wetland Trends in Michigan since 1800: A preliminary Assessment

[34] Wells, J.C. 2008. Longman pronunciation dictionary (3rd ed. ed.). Harlow, England: Pearson Education Limited/Longman. p. 313

[35] Wetzel, R. G. 1983. Limnology. (2nd Edition)

[36] Wigley T.M.L and P.D. Jones 1985. "Influences of precipitation changes and direct $\mathrm{CO} 2$ effects on stream flow 